\title{
„Krwawa droga” i „czarowna jazda". Z socjologii podróży w wieku XIX
}

\author{
Wacław Forajter
}




\title{
"Krwawa droga" $i$ „czarowna jazda". Z socjologii podróży w wieku XIX
}

\author{
Wacław Forajter
}

TEKSTY DRUGIE 2017, NR 6, S. 166-180

DOI: $10.18318 /$ td.2017.6.9

Postępująca globalizacja rozsadza warstwa po warstwie senne zasłony marzeń, chroniące to, co rodzime, zasiedziałe, zorientowane samo na siebie i z samego siebie czerpiące ozdrowieńcze siły życia zbiorowego - życia, które do ostatniej chwili zwykle było u siebie i w swych rodzimych krainach... ${ }^{1}$

Na wiosnę podobno, kto żyw, wybiera się za morze. ${ }^{2}$

Eric Hobsbawm w trzytomowej monografii XIX wieku zwrócił uwagę nie tylko na epokowe znaczenie ówczesnych rewolucji społecznych i przemian technologicznych, ale również na przeobrażenia w dziedzinie transportu, które sprawiły, że w ciągu kilkudziesięciu

1 P. Sloterdijk Kryształowy pałac. O filozoficzną teorię globalizacji, przeł.

B. Cymbrowski, Wydawnictwo „Krytyki Politycznej”, Warszawa 2011, S. 39 .

2 Z. Chełmicki WBrazylii. Notatki z podróży, t. 1, Skład główny w administracji „Słowa”, Warszawa 1892, s. 4.

\section{Wacław Forajter -}

adiunkt w Zakładzie

Historii Literatury

Poromantycznej Uni-

wersytetu Śląskiego.

Autor książek „Zły”

LeopoldaTyrmanda

jako „literatura środka".

Tekst i konteksty (2007)

i Kolonizator skoloni-

zowany. Przypadek

Sygurda Wiśniow-

skiego (2014) oraz

artykułów opubliko-

wanych w $_{\text {"Pamiętniku }}$

Literackim”, "Tekstach

Drugich“i „Wieku

XIX." Tłumacz Estetyki

fotografii Françoisa

Soulagesa (2007,

2012), esejów Paula

Valèry'ego i Jeana-Luca

Nancy'ego. Kontakt:

wforajter@oz.pl 
lat świat stał się znacznie mniejszy, a procesy globalizacyjne zaczęły dotyczyć nawet najbardziej oddalonych zakątków kuli ziemskiej. Decydującą rolę w tym procesie odegrał wynalazek napędu parowego. Za jego sprawą ludzie, których rodzice poruszali się wyłącznie pieszo, konno lub dzięki wehikułom napędzanym energią nóg zwierzęcych, a w zamorskie wojaże wybierali się powolnymi, zależnymi od sił przyrody żaglowcami, mogli podróżować szybciej i dalej. Co prawda, większość mieszkańców świata „wciąż żyła i umierała w miejscu swojego urodzenia, a ściślej: ich przemieszczanie się nie miało ani innego charakteru, ani większej skali niż przed rewolucją przemysłową" nach świata zachodniego prawdopodobnie tylko bardzo mała liczba mężczyzn i bardzo mała liczba kobiet nie zetknęła się w ciągu swojego życia z koleją"4.

Droga żelazna stała się wówczas jednym z głównym symboli cywilizacji technicznej i środkiem podróży dla osób niezależnie od ich płci, wieku czy klasy społecznej. Wszystkie one odczuwały zawrotną różnicę między pojazdami konnymi a nowym wynalazkiem, doceniając jednostajność „ruchu" i „lekkiego unoszenia się nad ziemią, bez szturchnięć, uderzeń” czy niezmienność „kierunku bez przejeżdżania na bok prawy i lewy, na dół i do góry, w esach i zygzakach, w ostrych i tępych kątach"5. Obok bezdyskusyjnych korzyści podróż koleją posiadała również stosunkowo liczne wady. Wojciech Tomasik zauważył na kartach Pociagu do nowoczesności: „Traumatyczny charakter doświadczenia nowoczesnego nigdzie nie daje o sobie znać dokuczliwiej niż w XIX-wiecznym podróżowaniu pociagiem. To kolej, a nie miasto, jest źródłem cierpień, o jakich nie śniło się wcześniej filozofom"6.

3 E. Hobsbawm Wiek kapitału 1848-1875, przeł. M. Starnawski, Wydawnictwo „Krytyki Politycznej", Warszawa 2014, s. 296.

4 E. Hobsbawm Wiek imperium 1875-1914, przeł. M. Starnawski, Wydawnictwo „Krytyki Politycznej", Warszawa 2015, s. 46.

5 Zob. L. Pietrusiński Wspomnienia z Wenecji, kolei żelaznej lipnicko-wiedeńskiej, Wiednia, Karpat Wadowickich, Frankfurtu nad Menem i przelotu z Krakowa do Tatr Spiskich, zebrał doktor prawa..., t. 1 (fragment), w: W. Tomasik Inna droga. Romantycy a kolej, Wydawnictwo IBL PAN, Warszawa 2012, s. 184. Tekst Pietrusińskiego pochodzi z 1845 roku, a więc powstał krótko po wybudowaniu pierwszych linii kolejowych w Cesarstwie Austriackim.

6 W. Tomasik Pociąg do nowoczesności. Szkice kolejowe, Wydawnictwo IBL PAN, Warszawa 2014, s. 16. W dalszej części książki badacz pisze o „sponiewieraniu, zezwierzęceniu, utracie tożsamości" jako konsekwencji podróży koleją, samą zaś pasażerskość nazywa "bolesną przygodą ciała” (tamże, s. 130, 131). 
Badacz niewątpliwie ma rację: doświadczenia tyranii rozkładu, niepożądanej bliskości, nudy, dojmującej klaustrofobii w zamykanym na czas jazdy wagonie i bezbrzeżnego strachu przed katastrofą same w sobie miały charakter egalitarny. Myli się jednak, kiedy sugeruje identyczne natężenie bodźców negatywnych w przypadku wszystkich pasażerów. Z pewnością bowiem zdecydowanie większą udrękę stanowiła podróż dla ludzi biednych, podróżujących nie tyle dla rozrywki i wiedzy, ile z konieczności ekonomicznej, jak np. Górnoślązacy wyjeżdżający do pracy okresowej w Niemczech czy mieszkańcy Kongresówki i Galicji, udający się do obu Ameryk. Mordęga ich stłoczonych ciał, ocierających się o siebie wśród brudnych przedmiotów, resztek żywności i wydzielin organicznych, sytuowała się na antypodach doświadczeń zamożnego kupca czy wytwornej damy, zatopionych w lekturze lub kontemplacji mijanego krajobrazu na miękkich, pluszowych fotelach luksusowej kuszetki lub wagonu pierwszej klasy. Skazanych, co prawda, na niepożądane spojrzenia i wymuszoną rozmowę, ale nie upychanych do maksimum w ograniczonej przestrzeni, lekceważonych przez obsługę pociągu i tratowanych na stacji przez ciągnącą do tego samego wyjścia rzeszę identycznych desperatów.

Józef Kremer, heglista i teoretyk sztuki, opisując podróż koleją z Krakowa do Szczawnicy w 1865 roku, zwrócił uwagę na alienujący charakter doświadczenia podróży kolejowej: „Każdemu da się we znaki, że jest tylko jedynką, najmizerniejszą jedynką w tej masie; wożą go pędem przez świat, jakby był tłumokiem lub listem, lub ostrygą, z którą strach, by nie zatęchła w drodze"”. Jako zagorzały czytelnik niemieckich idealistów nie mógł on oczywiście afirmować materialnych aspektów teraźniejszości, stąd tak ostro zaatakował maszynowy i masowy charakter przewozu koleją, zrównującego ludzką jednostkę z przedmiotem czy zwierzęciem niższego rzędu. W istocie jednak określenia te, jeśli wziąć pod uwagę sytuację pasażerów z trzeciej lub czwartej klasy, mają wyłącznie charakter mało fortunnych metafor, ponieważ w takich warunkach jak nędzarze zamożny profesor Uniwersytetu Jagiellońskiego nigdy nie podróżował. Pewne wrażenie o kondycji gorszych wagonów dają cztery ryciny Ksawerego Pillatiego, zamieszczone w numerze 537 „Kłosów” z 1875 roku i układające się w cykl Charakterystyka podróżujących koleja żelazna. Został on przedrukowany w Ikonie nowoczesności z adnotacją Tomasika: „Kolej, z jednej strony, demokratyzowała podróżowanie, z drugiej - ustalała nowe podziały, instytucjonalizując czterema klasami tradycyjną stratyfikację

7 J. Kremer Szczawnica (fragment), w: W. Tomasik Inna droga..., s. 165. 
społeczną"8. Jest to bodaj jedno z nielicznych miejsc we wszystkich czterech książkach, gdzie badacz w ogóle zwrócił uwagę na fakt, że pociąg uosabiał w tamtej epoce nie tylko optymistyczną ideologię postępu, ale również nowoczesne konflikty klasowe, objawiające się chociażby w amerykańskim strajku w zakładach George’a Pullmana (1894) oraz głośnych protestach francuskich pracowników sektora transportowego z pierwszej dekady XX wieku.

Znaczenie obrazów warszawskiego ilustratora modeluje przede wszystkim tytuł cyklu, nadając im charakter fizjologiczny, czyli zacieśniając ogląd przedstawionych scen do ukazanych w niej typów ludzkich jako przedstawicieli określonej grupy etnicznej, zawodu czy stanu: zamożnego przedsiębiorcy, ubranej zgodnie z paryskim szykiem arystokratki, średniozamożnej mieszczanki, ortodoksyjnego Żyda czy niańki z dzieckiem. Za Peterem Sloterdijkiem można osoby obecne w przedziałach dwóch pierwszych klas uznać za pasażerów sensu stricto, to znaczy klientów „usług transportowych”, którzy płacą, by odbywana podróż „nie stała się doświadczeniem, z którego później należałoby zdać sprawę”, i których „jedyna łączność z przemykającymi krajobrazami zawiera się w chęci ich przemierzenia"'. Podobnie jak ich prototyp, Phileas Fogg, dysponują oni kapitałem, umożliwiającym im wykup dostępu do większej przestrzeni, wygodnych foteli czy szerszych okien, zmieniających mijane widoki w fantasmagoryczne panoramy. Benjamin Gastineau, francuski dziennikarz i wolnomyśliciel, tak pisał o tym ostatnim doznaniu: „To potop fantastycznych figur, wznoszących się przed wami jak tajemnicze zagadki; to kabalistyczne sfinksy, smoki o ognistych oczach, dziwaczne chimery, przykucnięte gargulce, które wyciągają szyje ku jaskiniom o ziejących paszczach, hydry podnoszące miriady głów, oszalałe Gorgony splecione w walce $\mathrm{z}$ obrzydliwymi harpiami; grupy gnomów, wściekłe spółkowania lubieżnych syren o obfitych, pokrytych naroślami piersiach i gęstych

8 W europejskich posiadłościach zamorskich nakładały się na nią zasady biopolityczne, wynikające z konieczności zarządzania społecznościami wieloetnicznymi czy - jak powiedzieliby ludzie żyjący w "wieku imperium” (określenie Hobsbawma) - wielorasowymi. Podziały te odcisnęły znamię na biografii Mohandasa (Mahatmy) Gandhiego, który w "nocy z 6 na 7 czerwca 1893 roku w drodze do Pretorii został wyrzucony z pociągu na stacji w Pietermaritzburgu przez współpasażera i policjanta, którzy uważali, że jako «kolorowy» nie ma prawa podróżować z białymi. Zdarzenie to [...] uświadomiło mu, że należy walczyć z niesprawiedliwościami świata kolonialnego". K. Iwanek, A. Burakowski Indie. Od kolonii do mocarstwa 1857-2013, PWN, Warszawa 2013, S. 115.

9 P. Sloterdijk Kryształowy pałac..., s. 50. 
włosach, przeplecionych piniowym lasem, potworne cyklopy, których oczy są otchłanią!"10.

Z kolei podróżujący trzecią klasą, przedstawieni przez warszawskiego rysownika, siedzą na drewnianych, twardych ławkach, ścieśnieni do granic możliwości, twarzą do współpasażerów, noga przy nodze, bez minimalnego nawet dystansu: niemowlę zaczepia siedzącego obok chłopca, kobieta o wyglądzie guwernantki, jakby rozdrażniona tłokiem, wygląda przez szybę, a co w dużym, wiklinowym koszu wiezie charakterystyczny brodacz, wiedzieć raczy jedynie Jehowa. Z kolei pasażerowie czwartej klasy, wyglądający na chłopów czy sezonowych robotników, z braku innej możliwości siedzą na skrzynkach i na drewnianej podłodze, kobiety z dzieckiem stoją zaś przy otwartym niewielkim okienku, nie tyle podziwiając świat za oknem, ile raczej uciekając od panującego w wagonie zaduchu. Charakter przedstawienia ogranicza tę sytuację jedynie do aspektu wizualnego, nie mamy natomiast dostępu do jej sfery audialnej i zapachowej. Nie ulega jednak wątpliwości, że gdyby w środku znalazł się jeden z higienistów, opisanych przez Alaina Corbina na kartach We władzy wstrętu, wywęszyłby tam całą gamę niebezpiecznych, zagrażających społecznemu organizmowi woni"1. Bezsprzecznie również mamy do czynienia z ludźmi, którzy zostawili swoje domy i, z sercami pełnymi rozpaczy i nadziei, zmierzają ku „nieznanemu horyzontowi”2, w pogoni za lepszym bytem. Choć przeczy temu data publikacji litografii, chciałbym zobaczyć w nich polskich chłopów, którzy na początku lat 90. XIX wieku tłumnie wyruszyli do Ameryki Południowej. Literatura przedmiotowa

B. Gastineau La vie en chemin de fer, E. Dentu: libraire de la Société des Gens de lettres, Paris 1861, s. 52 [przekład mój - W.F.]. Skrajna literackość opisu Gastineau wynika, moim zdaniem, zarówno z inspiracji konwencją parnasizmu, jak i deformacji krajobrazu w trakcie podróży pociągiem, tzn. pozbawienia widoku materialnej "gęstości” na rzecz zjawiska, zaprzeczającego znanym praktykom widzenia. Tadeusz Sławek zauważył: „świat, który kolej przecina, jest obszarem ducha. Gdy kolej jest «żelazna», świat poza ścianami jej wagonów jest eteryczny, twardość materii ustępuje miejsca zwiewności zjawy..." (T. Sławek Demon ruchu. Próba fenomenologii kolei żelaznej, w: Z problemów literatury i kultury XX wieku. Prace ofiarowane Tadeuszowi Kłakowi, red. S. Zabierowski, Wydawnictwo Naukowe Śląsk, Katowice 2000, s. 152). Stąd "gdy rama szyby przedziału staje się ramą obrazu, to, czego nie rozumiem, i to, co ledwie widzę, co majaczy na pograniczu widzialności, nabiera sensu jako obraz, simulacrum rzeczywistości" (tamże, s. 154).

11 A. Corbin We władzy wstrętu. Społeczna historia poznania przez węch. Od odrazy do snu ekologicznego, przeł. A. Siemek, Oficyna Wydawnicza Volumen, Warszawa 1998. 
na temat "gorączki brazylijskiej" jest bardzo obszerna, a istniejące opracowania problemu wyczerpująco omawiają właściwy mu kontekst historyczny (zniesienie niewolnictwa w Brazylii, akcję werbunkową w Europie Środkowej, sytuację ekonomiczną polskich chłopów itd.) ${ }^{13}$. Prawie nikt jednak nie przyjrzał się temu zagadnieniu od strony warunków materialnych samej podróży, wytwarzających określone doznania sensualne i uczuciowe. Próbując wypełnić tę lukę, chciałbym więc sprawić, by we wnętrzach najtańszego wagonu i pomieszczeń na dolnych pokładzie statku znowu pojawiły się głosy, zapachy i emocje.

Wątkiem, który stale powraca w XIX-wiecznych - publicystycznych i literackich - opisach kolejnych etapów wędrówki za ocean, jest akcentowanie całkowitej niehumanitarności przejazdu. Na przykład publicysta „Nowej Reformy" porównywał transport emigrantów do przewozu nierogacizny, bardzo plastycznie zresztą oddając jego inne aspekty:

Nie znając celu podróży, losu, jaki ich czeka za morzem, ani krajów, do których mają trafić, ludzie oddają się ślepo w ręce najgorszych wyzyskiwaczy, a ci ładują ich niczym towar, upychają głodnych, zmarzniętych biedaków w wagony czwartej klasy. Wagon, którym przewozi się bydło, wygląda jak salonka w porównaniu z czwartą klasą, [...] wypchaną od podłogi po sufit ludźmi, tobołkami i workami z najprzeróżniejszymi rupieciami. Ludzie siedzą jeden na drugim, na piramidach tobołków i koszy leżą niemowlęta, upchnięte po jakichś kątach dzieciaki ryczą na całe gardło, ponieważ jest im zimno i głodno, gdzie indziej na gołej, brudnej ziemi kulą się osłabione i chore kobiety, na leżących matkach siedzi ich potomstwo. Ścisk nie do opisania, nie da się powiedzieć, do kogo należą poszczególne ręce i nogi. ${ }^{14}$

13 Zob. np. W. Breowicz Ślady Piasta pod piniorami. Szkic z dziejów wychodźstwa polskiego w Brazylii, Polonia, Warszawa 1961; Dzieje Polonii w Ameryce Łacińskiej. Zbiór studiów, red. M. Kula, Komitet Badania Polonii PAN, Wrocław 1983; K. Groniowski Polska emigracja zarobkowa w Brazylii 1871-1914, Instytut Historii PAN, Wrocław 1972; I. Klarner-Kosińska Emigracja z Królestwa Polskiego do Brazylii 1890-1914, Książka i Wiedza, Warszawa 1975; G. Marchwiński Z Brazylii do Polski. Chłopi, naród i literatura w dyskursie publicznym przełomu XIX i XX wieku („Pan Balcer w Brazylii” Marii Konopnickiej), "Pamiętnik Literacki” 2015 z. 2; A. Mocyk Piekło czy raj? Obraz Brazylii w piśmiennictwie polskim w latach 1864-1939, Universitas, Kraków 2005.

14 Cyt. za: M. Pollack Cesarz Ameryki. Wielka ucieczka z Galicji, przeł. K. Niedenthal, Wydawnictwo Czarne, Wołowiec 2011, s. 189. 
Doświadczenie skrajnej ciasnoty i zgiełku pojawia się również w Listach $z$ Brazylii Adolfa Dygasińskiego, który podróżował z emigrantami do Bremy. Zamiast czterdziestu pięciu osób w jego wagonie znajduje się ponad sześćdziesięciu pasażerów: „Na podłodze wszędzie porozlewane jest mleko, woda, pełno okruchów chleba, kości, ściany zamazane masłem, miodem i Bóg wie czym. Na poręczy suszą się pieluchy i pierzynki spod maleńkich dzieci"15. Z odzieży tułaczy paruje wilgoć, a w środku panuje taka temperatura jak „W cieplarni dla roślin egzotycznych" (LZB, 13). Mężczyźni nieustannie ćmią fajki i papierosy, wypełniając przestrzeń gryzącym dymem, niektórzy piją wódkę, w innym kącie zasypia matka z niemowlęciem, próbując nie słyszeć mamrotania pobożnych czy krzyków i przekleństw pijanych sąsiadów. Ostatniego słowa używam nieprzypadkowo - do Ameryki Południowej, w przeciwieństwie do Stanów Zjednoczonych, dokąd podróżowali głównie młodzi mężczyźni, jadą całe rodziny, nierzadko pochodzące z tej samej wsi. Tak więc, „polscy Brazylijczycy” podczas całej podróży obcowali z reguły głównie z rodziną i znajomymi. Na przykład w powieści Na złamanie karku, drobiazgowo odtwarzającej realia tułaczki, która dla wielu bohaterów stanie się ostatnią drogą, z Rokitnicy pod Rypinem wyrusza do Brazylii około osiemdziesięciu mieszkańców, w tym jedynie czterdziestu dorosłych ${ }^{16}$.

Pierwszy dłuższy postój następuje w berlińskim Charlottenburgu, gdzie emigranci mają zagwarantowany nocleg przed przesiadką do Bremy (NZK, 47). Pasażerowie zostają spędzeni do źle oświetlonej, olbrzymiej hali, której rozmiary nie są jednak wystarczające dla dwóch tysięcy osób (LZB, 17). Śpią na gołej ziemi wysłanej gdzieniegdzie słomą. W tłumie „widać jakieś figury, przenikliwie śledzące i oglądające ludzi" (tamże). Baczny obserwator czy agent policyjny niewątpliwie rozpoznałby $w$ nich przedstawicieli kryminalnej fauny, żerującej na tłumach zdesperowanych, zagubionych przybyszy. Polscy

\footnotetext{
A. Dygasiński Listy z Brazylii, Wydawnictwo „Kuriera Warszawskiego", Warszawa 1891, s. 13. Kolejne cytaty z książki lokalizuję w tekście i oznaczam skrótem LZB. Cyfra arabska po skrócie oznacza numer strony. W artykule wykorzystuję także inne skróty: NZK - A. Dygasiński Na złamanie karku. Powieść, Wydawnictwo "Kuriera Warszawskiego", Warszawa 1893; AOR - Abstracts of reports of the Immigration Commision, vol. II, Government Printing Office, Washington 1911; LE - Listy emigrantów z Brazylii i Stanów Zjednoczonych 1890-1891, do druku podali, wstępem opatrzyli W. Kula, N. Assorodobraj-Kula, M. Kula, Muzeum Historii Polskiego Ruchu Ludowego, Warszawa 2012. W przypadku ostatniej pozycji postanowiłem zachować oryginalną pisownię.

16 Zarówno chłopi Dygasińskiego, jak i nadawcy listów z antologii Kulów pochodzili z północnego Mazowsza, najczęściej z ziemi dobrzyńskiej.
} 
włościanie z terenów Królestwa Polskiego nie znają bowiem żadnego języka poza wiejską gwarą i kilkoma słowami po rosyjsku, dlatego są ustawicznie narażeni na kradzieże dobytku, próby wyłudzenia pieniędzy czy zakup fałszywych biletów. Nieprzypadkowo właśnie w stolicy Prus Matus Dzwonko z utworu Dygasińskiego zostaje spity do nieprzytomności i okradziony do ostatniego grosza przez zadomowionego w metropolii krajana.

W listach emigrantów, instruujących najbliższych, jak najbezpieczniej dotrzeć do Brazylii, często powtarza się zalecenie wzmożenia uwagi podczas podróży przez obczyznę. Niejaki Bakalarski, którego imienia nie przechowały żadne archiwa, tak pisał z Florianópolis do żony: „i pamiętaj, [...] zwłasca w Berlinie, bo w Berlinie to jak w piekle, jak tylko wysiądziesz z klasy czyli z wagonu zaraz wołaj swych bagaży i najlepi kóp sobie dózy kosz [w] Warszawie i w kosz popakój a reszte w sienniki...” (LE, 168). Wróg bowiem „czyha na każdym kroku, kryje się pod mundurem żandarma czy kolejarza, przedstawia się jako agent linii kolejowej, chce ukraść pieniądze, niekorzystnie je wymienić, żądać dopłat, które się nie należą"17. Stąd dominującym afektem, poza lękiem przed nieznaną przyszłością, stawała się paranoiczna podejrzliwość, do której z czasem dołączało poczucie upokorzenia. Podstawowymi zachowaniami, za pomocą których obsługa pociągu wchodziła w interakcję z Polakami, były bowiem krzyk i szturchnięcie, stanowiące w obliczu bariery językowej jedyną metodę wskazania kierunku czy rozwiązania problemu. Dotyczyło to zresztą także samego Dygasińskiego: „Ponieważ uchodzę za emigranta, więc poniewierają mną konduktorzy i szwajcarzy, a rzadko kiedy jest czas, aby się upomnieć o swoje prawa pasażera czwartej klasy. I mnie, i chłopów chwytają ciągle jacyś ajenci, wypytują, stręczą bilety, ale nic darmo; bronię siebie i chłopów, jak mogę, od tego paskudztwa, jednakże strasznie to trudno, gdyż szał zarobkowania na emigrantach jest wściekły" (LZB, 19) ${ }^{18}$.

Chłopi nie zawsze zdawali sobie sprawę z faktu, że w każdym momencie mogą się w Niemczech zgubić i nieustannie grożą im kłopotliwe nieporozumienia, wynikające nie tylko z nieznajomości języka, ale również kontekstu

17 W. Kula Wstęp, w: Listy emigrantów..., s. 59.

18 Pogardliwe - a nawet brutalne - traktowanie chłopów przez obsługę pociągów, transatlantyków oraz mniejszych statków, dostarczających ich w Brazylii na miejsce przeznaczenia, było w tamtym okresie normą. Polski reportażysta odnotował, między innymi, następującą sytuację: "Na okręcie nikt ich nic rozumiał, ani oni nikogo; pomiatano nimi pogardliwie, popychano ich, przerzucano. Raz się ująłem za jakąś kobietą w poważnym stanie, którą majtek tak silnie na bok odepchnął, że się do burty potoczyła; chciałem go w kark poczęstować, lecz drapnął, śmiejąc się szyderczo" (LZB, s. 83). 
kulturowego. W większości przypadków od katastrofy oddzielała ich jedynie „integracja grupy i wewnętrzna solidarność”, które służyły też „reakcjom obronnym wobec pochodzących z zewnątrz przejawów agresji" ${ }^{\prime 1}$. Na tym tle szczególnie dramatyczna wydaje się relacja Franciszka Płomianoskiego. Jej autor, podróżujący w pojedynkę chłop z Kujaw, opisuje bratu swoje perypetie w Niemczech: gdy dojechał do Berlina, dowiedział się od żandarmów, że nie ma już przejazdów do Brazylii; postanowił więc pojechać do Hamburga, by tam zaokrętować się jako majtek na okręcie do Stanów Zjednoczonych; po przybyciu na miejsce dowiedział się w porcie, że nie posiada niezbędnych kwalifikacji. I wtedy, jak pisze: „zaczułem się martwić i chodzić po Amburgu jak głupi, bo nie rozumiałem po niemiecku dopiero okropnie się martwiłem obłąkany, łzy my w oczach stanyły..." (LE, 138-139); dotarłszy do Bremy, zostaje poinformowany, że jako człowiek nieposiadający z sobą rodziny, nie jest uprawniony do, możliwego jednak dla innych, wjazdu do Brazylii; szansa na to pojawia się jednak przed nim, gdy poznaje rodzinę, która fikcyjnie go usynawia. Płaczący z bezsilności, pogrążony w niemocie mężczyzna, który niewątpliwie poznał grozę życia na pouwłaszczeniowej wsi polskiej - nic chyba dobitniej nie jest w stanie opisać sytuacji tych obcych miejskim przechodniom, wykorzenionych przybyszy. Niektórzy z nich, przekonani, że pieniądze zainwestowane w bilet oznaczają także darmowe noclegi i wyżywienie w mieście portowym, nierzadko wykazywali postawę roszczeniową i wchodzili w konflikty z mieszkańcami, co kilkakrotnie odnotował Dygasiński. Często sytuacje te wynikały z braku pieniędzy, spowodowanego właśnie przez działalność oszustów i naciągaczy. Jeden z emigrantów żydowskich, Manes Korzek, pisał do najbliższych z Hamburga: „Statek odchodzi w niedzielę. I myśmy dali agentowi 75 marek za mieszkanie i wikt i pozostali bez grosza, i na statku nie będziemy mieli za co kupić najpotrzebniejszej rzeczy" (LE, 154).

Emigranci, udający się za ocean, byli przewożeni pociągiem do portu w Bremerhaven, a tam wrzucani na dolny pokład gigantycznych transatlantyków. Jeden z bohaterów Na złamanie karku, Walek, zostaje przez marynarzy dosłownie wepchnięty do ogromnej sali, która kojarząc mu się wizualnie z piwnicznym „lochem” „jamą”, a zapachowo z zatęchłą „studnią”, niczym nie różni się od zwykłej ładowni. Słabe oświetlenie, brak miejsca, spowodowany nadmierną ilością piętrowych prycz, wszechogarniający zaduch i natłok kłębiących się wszędzie ciał potęgują w bohaterze poczucie skrajnego

19 B. Klimaszewski Pod znakiem potu, łez i dolara. Polonia amerykańska w zwierciadle literatury polskiej, Kraków 1990, s. 90. 
dyskomfortu. W rezultacie chłop ucieka z okrętu, całkowicie rezygnując z planów wyjazdu. Inny, bardziej drobiazgowy opis tej przestrzeni przynoszą Listy $z$ Brazylii. Skrajnie przepełnione dormitorium nazywa Dygasiński „podmorską sutereną" (LZB, 32), co w języku tamtej epoki ewokowało doznania chłodu, nieprzyjemnych woni, wilgoci i choroby. Dla podróżujących przeznaczone były piętrowe łóżka „z żelaznych prętów”, których kolejne rzędy były przedzielone mikroskopijną ("minąć się trudno”) przestrzenią. $\mathrm{Na}$ wysłanej słomą i wyposażonej w siennik oraz „poduszkę z trawy morskiej” koi „spoczywa jeden dojrzały człowiek (matka lub ojciec) i dziecko” (tamże). Ani jednak reportaż autora Beldonka, ani powieść z 1893 roku, która, operując często mową pozornie zależną, oddaje głos samym włościanom, nie ukazują tak sugestywnie horroru tej podróży jak urzędowy raport poświęcony realiom dolnego pokładu i przedstawiony Kongresowi Stanów Zjednoczonych w 1909 roku. Stanowił on rezultat pracy kilku specjalnych agentów, którzy, wcielając się w rolę ubogich emigrantów, przebyli ocean na dwunastu statkach należących do różnych kompanii ${ }^{20}$. Z dużym prawdopodobieństwem można założyć, że wśród nich znalazł się co najmniej jeden okręt bremeńskiego towarzystwa Norddeutscher Lloyd, które było najważniejszym graczem zarówno na trasie Niemcy- Nowy Jork, jak i obsługiwało większość rejsów pasażerskich do Ameryki Południowej. Statkiem tej linii właśnie płyną do Brazylii protagoniści Na złamanie karku, Dygasiński zaś, wraz z dwoma i pół tysiącami emigrantów, podróżował na parowcu „München”, który w ostatniej dekadzie XIX wieku przewiózł na oba kontynenty setki nędzarzy z Europy Środkowo-Wschodniej.

Twórcy raportu, przedstawiając charakterystykę dolnego pokładu, nazywają panujące na nim warunki „tak szkodliwymi dla zdrowia i dobrych obyczajów [morals], że nic na lądzie nie może się z nimi równać. To, że ludzie mieszkają tam jedynie czasowo, nie jest żadnym usprawiedliwieniem" (AOR, 299). Sformułowania tego w żaden sposób, w kontekście podanych faktów, nie można uznać za retoryczną emfazę, a powaga tego zarzutu rysuje się tym wyraźniej, im bardziej pamiętamy o prymitywizmie ówczesnej egzystencji wiejskiej i o tragicznych warunkach lokalowych, w jakich żył

Był to jeden z efektów pracy komisji pod przewodnictwem senatora Williama P. Dillinghama (tzw. Dillingham Comission), powołanej przez amerykański rząd do zbadania zjawiska imigracji, a działającej w latach 1907-1911. W raporcie rozróżnia się dolny pokład "starego" i "nowego" typu. Na drugim z nich panowały znacznie lepsze warunki, ale, jak sygnalizują twórcy raportu, występował on wyłącznie na niewielu statkach, przywożących emigrantów z północnej Europy (zob. AOR, 299 in.). 
XIX-wieczny proletariat. W kilku olbrzymich pomieszczeniach sypialnych mieszka ponad dwa tysiące osób - z pobieżnych rachunków Dygasińskiego wynika, że w każdym z nich przebywało około ośmiuset pasażerów, czyli dwukrotnie więcej, niż było łóżek. Z reguły piętra pryczy oddzielała od siebie odległość nieco ponad sześćdziesięciu centymetrów, a łóżko, mierzące sto osiemdziesiąt centymetrów długości i pół metra szerokości, było w zasadzie jedyną przestrzenią, do jakiej posiadacz najtańszego biletu miał niepodważalne prawo (AOR, 296) ${ }^{21}$. W ogóle nie istnieje osobne miejsce na bagaż worki, torby czy kufry, zawierające z reguły cały rodzinny dobytek, także musiały leżeć na koi, podobnie jak cała garderoba pasażera, przybory toaletowe oraz sztućce i miski, dostarczane niekiedy podróżującym przez same linie (tamże). Łóżka oraz ich zawartość, aż do końca rejsu, w ogóle nie interesowały stewardów, których jedyną aktywnością w sypialniach było zamiatanie śmierdzących, pokrytych śmieciami i wilgotnych podłóg. W tej przestrzeni przez co najmniej kilkanaście dni żyli, kochali się, kłócili, bili, okradali, rodzili i umierali ludzie.

Dolegliwością, która spotykała na morzu wszystkich pasażerów, była choroba morska. Inaczej jednak przeżywała związane z nią niedogodności osoba zajmująca komfortową kajutę, a inaczej przechodził ją lokator dolnego pokładu. Bakalarski przestrzegał w liście żonę: „I pamiętaj, moja Zono, właś na gurne łuszka, obiesz jedne sobie dla siebie i dzieci, na dolne nie właś, bo jak zacną zygać z gurnych łuzek to prosto tym co na dolnych łuszkach lezą to łep zygają, co za przyjemność, więc tzymajcie się gurnych łuzek" (LE, 169). Według informacji z raportu wymiociny często nawet przez kilka dni leżały na ziemi, zanim zostały posprzątane (AOR, 296-297). Cierpiącym nie dostarczano bowiem żadnych pojemników; nie mieli też oni zapewnionej opieki lekarskiej, musieli więc liczyć jedynie na życzliwość współtowarzyszy. Co więcej, nawet na wyższych, zamkniętych pokładach, gdzie luki zapewniały dodatkowe środki wentylacji, stan powietrza wołał o pomstę do nieba. Stąd, jak wynika z raportu, pasażerowie, wyleczeni z choroby morskiej, często nadal nie opuszczali łóżek, cierpiąc na „rodzaj stuporu wywołanego duchotą" (AOR, 297). Dygasiński tej specyfiki dolnego pokładu kompletnie nie zauważył, oskarżając wiejskie kobiety, leżące przez całe dnie w łóżkach, „wśród mnóstwa gratów i artykułów żywności", a i zapewne robactwa, o chroniczne lenistwo, które przeciwstawił męskiej dbałości o dzieci (LZB, 41). To przytępienie zmysłu obserwacji wynikało zapewne z faktu, że wysłannik „Kuriera Warszawskiego” oddzielił 
się w Bremie od chłopskiego tłumu, wykupując droższy bilet i zajmując pojedynczą kabinę na górnym pokładzie. Pisarz, sugerując w Listach z Brazylii, że podróżował do Ameryki w identycznych warunkach jak chłopi i wyłącznie pro publico bono, przemilczał komfort, jaki zapewniły mu pieniądze hojnej redakcji. Informował o nich natomiast całkowicie otwarcie w prywatnej korespondencji, co odkryła Mirosława Radowska-Lisak. W jednym z pierwszych listów pisał: „Na statku jest mi bardzo dobrze, mam wszelkie wygody"22, a w kolejnych donosił o "serwowanych codziennie na parowcu: filiżance kawy, bułce z masłem i befsztyku" oraz wygodnym łóżku «miękkim jak pierze»"23. Sprzeczność między misją publiczną jako oficjalnym celem podróży a radością opływającego w dostatki turysty obrazuje także jeden z podstawowych paradoksów polskiego pozytywizmu, który, pochylając się nad biedą i wykluczeniem, nie chciał jednocześnie wyrzec się wielkopańskich nawyków.

Czego zatem nie zobaczył Dygasiński, ograniczający się w trakcie podróży przez Atlantyk do podsłuchiwania rozmów chłopów, którzy wyszli tam, by zaczerpnąć świeżego, nieskażonego chorobliwymi miazmatami powietrza? Na pewno nie zaglądał do łazienek i ubikacji, w których panowały skrajnie niehigieniczne warunki: ciasne pomieszczenia, których wyposażenie zostało wykonane z najtańszych materiałów, co znacząco utrudniało utrzymanie ich w czystości, nie zapewniały nawet minimum prywatności (AOR, 297); ich podłogi były mokre i kleiły się od brudu, pozostając nierzadko w takim stanie aż do ostatnich dni podróży, kiedy myto je przed wizytą inspekcji (tamże). Same klozety składały się z „plugawych”, jak wówczas pisano, nigdy nieczyszczonych rynien ${ }^{24}$. Polski pisarz, bez wątpienia, miał też do dyspozycji ręczniki oraz mydło - przywilej niedostępny dla pasażerów dolnego pokładu, którzy musieli radzić sobie ze wszechogarniającym nieładem jedynie za pomocą kilku kranów z zimną wodą morską (AOR, s. 298), spływającą do zapchanych odpadami, prowizorycznych umywalek. Krany te służyły zresztą również do mycia naczyń po posiłkach, zjadanych najczęściej, z powodu braku osobnego pomieszczenia, na kojach lub, w przypadku odpowiedniej pogody, na otwartym pokładzie, który zresztą na tym poziomie okrętu był stosunkowo

22 M. Radowska-Lisak Dwie wersje „brazylianidy” według Adolfa Dygasińskiego, w: Podróż i literatura 1864-1914, red. naukowa E. Ihnatowicz, Wydawnictwo Wydziału Polonistyki UW, Warszawa 2008, s. 411.

24 A.L. Fairchild Science at the Borders: Immigrant Medical Inspection and the Shaping of the Modern Industrial Labor Force, Johns Hopkins University Press, Baltimore 2003, s. 87. 
niewielki i nie zawsze ze względu na warunki pogodowe można było z niego korzystać (AOR, 299). Wszystkie te elementy składały się na doświadczenie, „które osłabiając ciało i zagnieżdżając tam zarazki rozwijającej się później choroby" (tamże) ${ }^{25}$, mogło jeszcze pogorszyć, i tak już podłe, chłopskie życie. Choroby były zresztą częścią każdego rejsu do Brazylii, dotykając zazwyczaj najmłodszych pasażerów - wysłannik „Kuriera” wspominał, że w trakcie epidemii szkarlatyny i błonicy dwaj lekarze okrętowi przyjmowali nawet do pięćdziesięciu pacjentów ${ }^{26}$. Autor Zająca najprawdopodobniej nie miał także żadnego kontaktu z charakterystycznymi zapachami dolnego pokładu: wonią stęchlizny, odorem niedomytych, przepoconych ciał i zastarzałego dymu tytoniowego, z którymi przed dobiciem do portu mieszał się przenikliwy smród środków dezynfekcyjnych.

Edward A. Steiner, autor słynnej książki On the Trial of the Immigrant z 1906 roku, tak podsumował podróż do Ameryki na pokładzie statku „Teutonic”: "[te] dziewięć dni na morzu niczym się nie różniły od dziewięciu dni odsiadki [prison]"27. Analogia między przepełnionym dolnym pokładem statku i więzieniem to nie tylko mniej lub bardziej udana przenośnia. Oba typy przestrzeni zostały bowiem zaliczone przez Michela Foucaulta do heterotopii - czyli nie-miejsc, posiadających „osobliwą właściwość pozostawania w relacji ze wszystkimi innymi miejscami [emplacements], ale w taki sposób, że zawieszają, neutralizują lub odwracają zastany układ relacji, który jest przez nie

Wniosek ten można wpisać w ramy dyskursu higieny, który wyłonił się w drugiej połowie XIX wieku w związku z odkryciami Ludwika Pasteura i kładł nacisk na konieczność częstych ablucji, mających powstrzymać rozprzestrzenianie się niebezpiecznych drobnoustrojów. Lęk przed bakteriami przybrał wówczas wręcz histeryczną postać, pojawiły się także pierwsze teksty utopijne, gdzie kondycja idealnych miejsc była ściśle uzależniona od przestrzegania zasad absolutnej czystości. Taki charakter miała metropolia France-Ville z powieści Pięćset milionów hinduskiej władczyni (Cinq cents millions de la Bégum) Jules'a Verne'a i Paschala Grousseta, czy wizja Marsa w Uranii Camille’a Flammariona, gdzie "wykorzeniona” została „wszelka zgnilizna: usunięto fermenty, powietrze jest nieskażone, fizjologia samowystarczalna". Cytat oraz informacje o specyfice ówczesnej higieny pochodzą z książki Georges'a Vigarello. Zob. G. Vigarello Czystość i brud. Higiena ciała od średniowiecza do XX wieku, przeł. B. Szwarcman-Czarnota, Wydawnictwo W.A.B., Warszawa 1998, s. 217-218.

Zob. także: „W czasie tych upałów podrównikowych rozmnożyły się nadzwyczajnie między ludźmi pasożytne owady; u jednych dzieci głowy pokryły się zupełnie szpetnemi strupami, innym znowu wystąpiły na całej skórze pęcherze, które pękały i sprawiały bardzo przykre swędzenie" (NZK, 118). Śmiertelność wśród nieletnich była stosunkowo wysoka. Właśnie z tego powodu jeden z chłopów nazwał podróż do Ameryki "krwawą drogą" (por. LE, 262). 
wskazywany czy odzwierciedlany"28. Statek, postrzegany przez francuskiego filozofa jako heterotopia par excellence, $\mathrm{w}$ przypadku parowca $\mathrm{z}$ emigrantami najpełniej odzwierciedlał jedną z głównych cech charakterystycznych dla tych specyficznych enklaw w ogóle: „sytuację absolutnego zerwania ze swoim tradycyjnym czasem"29. Chłopi, podróżujący do Brazylii, na morzu pozostawali zawieszeni pomiędzy cyklem pór roku typowym dla półkuli północnej i całkowicie determinującym ich dotychczasową egzystencję oraz czasem południowoamerykańskiej przyrody „na opak”, który całkowicie przeobraził codzienne praktyki i system pracy przybyszów z Europy Środkowej; między reliktami feudalizmu i „środowiskiem produkcji drobnotowarowej, zmierzającej do kapitalizmu"30. Ten swoisty międzyczas był również krótkotrwałym okresem wzmożonej nadziei na poprawę losu i epoką cudu - jak wynika z omawianych tekstów, chłopska „myśl nieoswojona”, pozbawiona zaplecza wiedzy naukowej, często przedstawiała niepojęte zjawiska przyrodnicze i klimatyczne w kategoriach bajecznych lub stricte religijnych. I tak fakt przekroczenia równika („na drugą stronę słońca") jest postrzegany przez jednego z włościan jako doświadczenie zaburzające spokojny przebieg rejsu: „okręt się tak trzy razy bujnął, że ludzie z łóżek pozlatali...", a ryby „skakały jak wieprze” (LE, 237). Nieznane zwierzęta morskie przypominają mazowieckim włościanom „bajeczne smoki, ukute z żelaza lub spiżu" (NZK, 121), metalową zaś konstrukcję statku objaśniają oni tym, że przez dwa dni będzie „płynął po wrzącej wodzie i dlatego okręt okuty [...], boby się drzewo rozgotowało" (LZB, 46).

Parowiec ostatnich dekad XIX wieku z systemem pokładów stanowił również figurę dwóch równoległych kontinuów podróżowania. Pierwszy z nich był obszarem komfortu, rozpościerającym się między kajutą Dygasińskiego a miękkimi dywanami, deptanymi nogami milionerów na górnym pokładzie

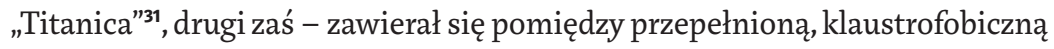

M. Foucault Inne przestrzenie, przeł. A. Rejniak-Majewska, „Teksty Drugie” 2005 nr 6, s. 121.

Tamże, s. 123.

W. Kula Wstęp, s. 117 .

Słynny statek „stanowił bardzo specyficzną przestrzeń urbanistyczną, w której dominowała wielkomiejskość połączona jak gdyby z kurortem. Była to przestrzeń wyjątkowego luksusu, w której mieściły się: biblioteka, sala koncertowa, kilka restauracji i kawiarni, łaźnie i basen «do kąpieli» pod nadzorem lekarzy, boiska sportowe [do tenisa oraz krykieta - W.F.] i pomieszczenia gimnastyczne, poczta, stacja telefoniczna, apteka, straż ogniowa, zakład fryzjerski i atelier fotograficzne". K. Stępnik Titanic. Recepcja katastrofy w prasie polskiej (1912), Wydawnictwo UMCS, Lublin 2012, s. 32. 
sypialnią transatlantyku a pogrążoną w mroku ładownią, w której przewożeni są chińscy robotnicy kontraktowi z opowiadania Wacława Sieroszewskiego (Kulisi).Te oba nieprzenikliwe dla siebie światy spotykały się tak naprawdę jedynie w momencie katastrofy, w obliczu śmierci, która unieważnia wszystkie różnice.

\section{Abstract}

\section{Wacław Forajter}

UNIVERSITY OF SILESIA (KATOWICE)

'The Bloody Path' and 'Breathtaking Ride': The Sociology of Travel in the Nineteenth Century

Forajter examines class-based distinctions of nineteenth-century travel with a focus on the economic migrants from the Polish peasantry to Brazil in the 1890s. Source texts include literary works, journalism and correspondence from the period in question. The key issues are perceptions of time and space during the journey as well as descriptions of material conditions determining affective and sensory experiences. Using sources that remain unpublished in Polish, Forajter demonstrates that poor emigrants were transported like cargo; he also points out the heterotopia of the means of transportation used for this purpose.

\section{Keywords}

travel, peasantry, Brazil, social class, heterotopia 